\title{
The Impact of Human Capital on Shanghai's Economic Growth
}

\author{
Song Yanan \\ School of Business \\ Macau University of Science and Technology \\ Macau, China \\ ynsong@must.edu.mo
}

\begin{abstract}
This paper adopts the economic data from 1978 to 2014, Shanghai as the research sample, to verify the relations of human capital and economic growth in Shanghai by using VAR and variance decomposition methods. The paper finds there are long-term equilibrium between both Shanghai material capital and human capital and economic growth. From the covariance equation we can get that the effect of investment in the physical capital at current stage is better than the investment in human capital stock. But the contribution of human capital is gradually improved in the process of continuous development and might exceed the contribution of material capital in the near future, which indicates enhancing the local human capital stock would enhance the sustainable development of the economy.
\end{abstract}

Keywords-Human Capital; Economic Growth; Shanghai; VAR; Variance Decomposition

\section{INTRODUCTION}

China has entered a new round of growth through a series of policy adjustments to encourage scientific and technological development. The development of science and technology depends largely on human development. Sun Shuo (2016) [1] and Teixeira (2016) [2] found that the regions with higher human capital stock had higher development speed because the feedback of input of human capital to the economy will be bigger than the input of other factors. Marek Radvansky (2011) pointed out that all the variables on human capital have a significant effect on the European economy and GDP [3]. Mark Roger (2003) [4], Rob A. Wilson (2004) [5] all found human capital as an important driving force and endogenous impact on economic growth.

According to the "13th Five-Year Plan" of Talent Development in Shanghai, Shanghai will focus on building scientific research centers with global influence and modern international metropolis to attract outstanding talents at home and abroad, and to improve the international competitiveness of Shanghai talents and innovative entrepreneurial ability by constantly optimizing the development of human capital environment, promoting the innovation and development and economic upgrading, to ensure the provision of strong The talent protection and solid intellectual support. In the existing research, Wang Chao (2004) [6] used the panel data to study the relationship between investment and GDP in the use of fiscal expenditure in various regions of our country and found the contribution of education investment was much higher than the other elements. Yan Quanzhi (2016) [7] analyzed the contribution of human capital to economic growth in Henan Province, and found the contribution rate of human capital stock in Henan Province is lower than the contribution rate of material capital stock. In this paper, the contribution of human capital to the development of human resources in Shanghai is based on the analysis of the current situation of human capital accumulation in Shanghai, which will use the Douglas Production Function to examine the relationship between human capital and economic growth.

\section{Methodology}

The focus of production and output lies in the input of various elements in the production process. According to the production function, when the input elasticity of the two elements reaches 1 , it is regarded as the most balanced and the output value at this time will be in the optimal state. But from a realistic point of view, this equilibrium state generally does not exist, because the output of the economy in the underdeveloped areas depends on capital investment which could increase the economic output rapidly. But with the diminishing marginal benefits and material investment saturation, a large number of capital inputs cannot play a very efficient role. While human capital investment could bring a better output effect, which have very common examples in developed countries who experienced the industrial revolution. When the capital investment is greatly strengthened, and reaches the peak at a certain point, then the government will begin to practice a series of policies to promote human capital, the input and output of human capital will gradually increase, to achieve the same effect with the capital investment output.

This paper chooses the unstructured method to establish the vector auto regression (VAR) model to analyze the relationship between economic growth and material capital and human capital in Shanghai. The use of VAR model can not only explore the impact of these two factors on economic growth to observe the role of economic development in the input of these two elements.

VAR model shows the evolution of a set of $k$ variables (endogenous variables) over the same sample period $(t=1 \ldots \mathrm{T})$ as a linear function of only their past evolution. The variables 
are collected in a $\mathrm{k} \times 1$ vector $y_{t}$, which has as the $\mathrm{i}^{\text {th }}$ element $y_{i}$.

$$
\begin{aligned}
& \text { A (reduced) p-th order VAR, denoted VAR (p), is } \\
& y_{t}=c+\phi_{1} y_{t-1}+\cdots+\phi_{p} y_{t-p}+\varepsilon_{t}
\end{aligned}
$$

Where $\mathrm{c}$ is a $\mathrm{k} \times 1$ vector of constants (intercept), $\phi_{i}$ is a $\mathrm{k} \times \mathrm{k}$ matrix (for every $\mathrm{i}=1 \ldots \mathrm{p}$ ) and $\varepsilon_{t}$ is a $\mathrm{k} \times 1$ vector of error terms. The VAR models for estimating the relations of human capital and GDP in Shanghai go as

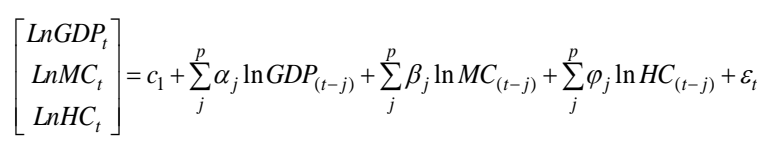

Where GDP is gross domestic product in Shanghai, MC is physical capital stock, $\mathrm{HC}$ is human capital stock, $\mathrm{C}$ is constant, and $\varepsilon$ is random Error term, $\mathrm{p}$ is the lag period.

\section{DATA}

The data set of this study consists of yearly observations covering the period from 1978 to 2014 . The GDP is derived from the "Shanghai Yearbook 2015" and is calculated by constant dollar GDP $(\mathrm{t}=1978)$. Since the development of China is relatively fast in the past two years, the data of each year are calculated at the current economic level. Current dollar GDP is calculated using today's dollars and makes comparisons between time periods difficult because of the effects of inflation. Constant dollar GDP solves this problem by converting the current information into some standard era dollar, in this paper means 1978 dollars. This process factors out the effects of inflation and allows easy comparisons between periods.

The material capital stock includes fixed capital and working capital. The working capital means that the value of the material capital stock is transferred to the new product in the process of production after the completion of the product sales, such as raw materials, semi-finished goods and other inventory. Fixed capital refers to the value of the capital is gradually transferred to the products in the production process, such as machinery and delivery room. According to the perpetual inventory method founded by Goldsmith in 1951, the current capital stock is equal to the previous period of capital stock deduction of current depreciation plus the current investment. This paper uses the estimated base capital stock of 361.30 in 1978 as the base capital stock (Liao Yuansu, 2012 [9]). The depreciation rate is based on the $9.6 \%$ set by Zhang Jun (2004) [8].

For the evaluation of human capital, this paper uses the average number of years of education to estimate the human capital which also used by Liao Yuansu (2012) [9]. The number of laborers and the degrees of education for the laborers are obtained from the China Labor Statistical Yearbook from 1978 to 2014, which can calculate the total amount of human capital stock.

\section{A. Unite Root Tests}

This paper couches the model in logarithmic difference form to induce stationary. The legitimacy of this is establishing using Augmented Dickey-Fuller test (ADF). The results are presented in Table 1 and they confirm that the log changes are all without intercept and trend. The test statistic of ADF are compared with critical values given in MacKinnon (1991). To ensure that disturbance variables in all these equations are white noise, a sufficient number of lagged differences or truncated lag, have been estimated using Akaike Information Criteria (AIC).

TABLE I. ADF SEQUENCE STATIONARY TESTING

\begin{tabular}{|c|c|c|c|c|c|}
\hline- & $\begin{array}{c}\text { ADF } \\
\text { Statistic }\end{array}$ & P Value & Variable & $\begin{array}{c}\text { ADF } \\
\text { Statistics }\end{array}$ & $\begin{array}{c}\text { P } \\
\text { Value }\end{array}$ \\
\hline LNGDP & 0.07225 & 0.6994 & $\Delta$ LNGDP & -7.1038 & $0.0000^{*}$ \\
\hline LNMC & 1.27221 & 0.9453 & $\Delta$ LNMC & -3.0036 & $0.0446^{*}$ \\
\hline LNHC & 2.52495 & 0.9987 & $\Delta$ LNMC & -6.3104 & $0.0000^{*}$ \\
\hline
\end{tabular}

Unit root tests on the first difference of all series show the rejection of null hypothesis in 1 level form in the autoregression representation of each variables, that means they are all I(1). Furthermore, the choice of lag lengths, 3, for the VAR is chosen on the basis of several statistical criteria.

\section{B. Johansen-Juselius Cointegration Test}

The cointegration level determined by ADF and PP tests allows us to check for the existence of the long run relationship between our variables using the cointegration test. It consists of checking the cointegration relation among variables while avoiding spurious results in case data are non-stationary. One of the main advantages of the Johansen and Juselius (1990) maximum likelihood method over other cointegration tests is that it can check for more than one existing cointegrating (i.e. long run) relationships among the variables [10]. If the cointegration analysis indicates that there is a cointegrating vector, we infer that the tested series will not drift apart in the longterm, and will revert to equilibrium levels following any short-term drift that may take place. In the context of this study, the null hypothesis is that no cointegration relation exists and rejecting the null allows us to infer that both indicators are interrelated with each other in the long run.

TABLE II. JOHANSEN-JUSELIUS COINTEGRATION TEST

\begin{tabular}{|c|c|c|c|c|c|}
\hline $\begin{array}{c}\text { No. of } \\
\text { CE(s) }\end{array}$ & $\begin{array}{c}\text { EigenVa } \\
\text { lue }\end{array}$ & $\begin{array}{c}\text { Trace } \\
\text { Statistic }\end{array}$ & P Value & $\begin{array}{c}\text { Max- } \\
\text { Eigen } \\
\text { Statistic }\end{array}$ & $\begin{array}{c}\text { P } \\
\text { Value }\end{array}$ \\
\hline None & 0.2866 & 24.4927 & $0.0470^{*}$ & 11.820 & 0.3138 \\
\hline At most 1 & 0.2532 & 12.6724 & $0.0436^{*}$ & 9.7559 & 0.0896 \\
\hline At most 2 & 0.0799 & 2.91645 & 0.1037 & 2.9164 & 0.1037 \\
\hline
\end{tabular}

Table II shows there are two cointegration relations exists. The coefficients of regressions are statistically significant at 5 percentages, and the regression models pass the general significance test. And every models' inverted roots of the lag polynomial lie inside the unit circle, denoting the stationary condition for general AR processes. 


\section{EMPIRICAL RESULTS}

\section{A. VECM Results}

Table III shows the coefficients in the cointegrating equation give the estimated long run relationship among the variables, whereas the coefficient of the error correction term ecm in the VECM estimation shows how deviations from the long run equilibrium affect changes in the variable in the next year; the other coefficients provide estimation of short run association between the FDI outflows of China to Brazil and trade variables of different products.

TABLE III. VECTOR ERROR CORRECTION MODEL ESTIMATION RESUlTS

\begin{tabular}{|c|c|c|}
\hline & LNGDP & LNMC \\
\hline LNGDP & 0.00 & $1.580^{* *}$ \\
\hline LNMC & $0.657^{* *}$ & 0 \\
\hline LNHC & $0.199^{*}$ & $-0.141^{*}$ \\
\hline C & 0.599 & -2.236 \\
\hline R-squared & 0.137280 & 0.859344 \\
\hline Adj.R-squared & -0.094991 & 0.821475 \\
\hline Sum sq.resids & 0.096142 & 0.001867 \\
\hline S.E.equation & 0.060809 & 0.008474 \\
\hline F-statistic & 0.591033 & 22.69258 \\
\hline Log likelihood & 51.51709 & 118.5214 \\
\hline Akaike AIC & -2.559829 & -6.142112 \\
\hline Schwarz SC & -2.200685 & -6.142112 \\
\hline Mean dependent & 0.095845 & 0.113617 \\
\hline S.D dependent & 0.058112 & 0.020056 \\
\hline
\end{tabular}

The coefficient reflects the long-term impact of Shanghai's human capital stock on GDP. 1\% of increase of physical capital (LNMC) causes GDP increase by $0.657 \%$ in Shanghai. And $1 \%$ of increase of human capital (LNHC) causes GDP increase by $0.199 \%$ in Shanghai. The impact of Shanghai material capital stock on economic growth is greater than the impact of human capital. In the meanwhile, $1 \%$ of increase of GDP causes physical capital (LNMC) increase by $1.58 \%$ in Shanghai. And 1\% of increase of GDP causes human capital (LNHC) increase by $11.202 \%$ in Shanghai. The impact of Shanghai material capital stock on economic growth is greater than the impact of human capital.

\section{B. Variance decomposition}

In econometrics and other applications of multivariate time series analysis, a variance decomposition is used to aid in the interpretation of a vector autoregression (VAR) model once it has been fitted. The variance decomposition indicates the amount of information each variable contributes to the other variables in the autoregression. It determines how much of the forecast error variance of each of the variables can be explained by exogenous shocks to the other variables.
TABLE IV. VARIANCE DECOMPOSITION

\begin{tabular}{|c|c|c|c|c|}
\hline Period & S.E. & LNGDP & LNMC & LNHC \\
\hline 1 & 0.053985 & 100 & 0.00 & 0.00 \\
\hline 2 & 0.063165 & 97.80 & 1.06 & 1.13 \\
\hline 3 & 0.070763 & 96.61 & 2.11 & 1.27 \\
\hline 4 & 0.077085 & 94.41 & 4.05 & 1.54 \\
\hline 5 & 0.082451 & 90.55 & 6.66 & 2.79 \\
\hline 6 & 0.087807 & 85.27 & 9.83 & 4.91 \\
\hline 7 & 0.093370 & 78.70 & 13.42 & 7.87 \\
\hline 8 & 0.099469 & 71.24 & 17.16 & 11.59 \\
\hline 9 & 0.106273 & 63.36 & 20.82 & 15.82 \\
\hline 10 & 0.113899 & 55.53 & 24.17 & 20.30 \\
\hline
\end{tabular}

It can be seen from the above table that the contribution of LNMC to LNGDP in Shanghai reaches the maximum at 10th period, and the contribution of LNHC to LNGDP is significantly improved after the 8th period. It shows that the contribution of input and output of material stock in Shanghai is better than that of human capital in the early stage, but the contribution of input and output of human capital will gradually increase, and in the tenth period which has reached $20.30 \%$, and is almost equal to the contribution of material capital.

From the long-term relationship, there are long-term equilibrium between both Shanghai material capital and human capital and economic growth. From the covariance equation we can get that the effect of investment in the physical capital at this stage is better than the investment in human capital stock. But the contribution of human capital is gradually improved in the process of continuous development and might exceed the contribution of material capital in the near future.

\section{CONCLUSION}

From this study, we found that in the process of economic development the capital investment and human input are essential parts of the production and the long-term stability of the economy growth. At present Stage, Shanghai's economic development mainly relies on the investment of material capital. And human capital investment has not exceeded the material capital. Shanghai is one of the world's financial centers, its development has been inseparable from the investment of all aspects. These investments promote the rapid development of Shanghai's economy, and make Shanghai one of China's most representative financial cities.

Although the impact of Shanghai's human capital is less than the impact of material capital, its contribution to the economy growth is increasing year by year. And Shanghai's human capital occupies an increasingly important position recent years. In the rapid economic development, the capital stimulus to the economy began to decline; the investment of human capital will continue to promote the economic development by increasing investment in education, medical and other industries. Thereby enhancing the local human capital stock would enhance the sustainable development of the 
economy. And because of the rapid development of a regional economy, Shanghai will also attract a large number of foreign workers and high-quality talent to seek development, which is why Shanghai has always attract so many young people to migrant.

\section{REFERENCES}

[1] Sun Shuo. Analysis of the Impact of Human Capital on Regional Economic Growth. Business Economics Research, 2016, 05.

[2] Teixeira. Economic growth, human capital and structural change: A dynamic panel data analysis, Research Policy, Volume 45, Issue 8, October 2016, Pages 1636-1648.

[3] Marek Radvansky.The Contribution of Human capital to European Economic Growth: An empirical exploration from a panel data. Tiruneh, Radvansky, Ecomod2011.

[4] Mark Rogers, A Survey of Economic Growth [M], 2003.
[5] Rob A. Wilson, Geoff Briscoe.The impact of human capital on economic growth : a review.vocational training research in Europe: background report. Luxembourg: Office for Official Publications of the European Communities, 2004

[6] Wang Chao. Empirical study on China's education and economic growth [J], Statistics and Information Forum, 2004, 06.

[7] Yan Quanzhi. An Empirical Analysis on the Contribution of Human Capital to Economic Growth - Based on the Analysis of Time Series Data in Henan Province [D], Heilongjiang Higher Education Research, 2016

[8] Zhang Jun, et al. China's inter-provincial material capital stock estimates: 1952-2000. Economic Research .2004 (10): 35-44

[9] Liao Yuansu. Human Resources Estimation of Employees in Shanghai (1978 2010). Shanghai Journal of Economics, Editorial Office, 2012,12

[10] Johansen, S. and Juselius, K., "Maximum Likelihood Estimation and Inference on Cointegration with Applications to the Demand for Money," Oxford Bulletin of Economics and Statistics.1990, Vol. 52, No. 2, pp. 169-210. 